\title{
Demokrasi Dan Kepemimpinan
}

\section{Transformatif}

\author{
Prof. R. Siti Zuhro, MA, PhD
}

rszuhro@gmail.com

\begin{abstract}
Abstrak
Pasca Reformasi 1998 Indonesia masasuki era kehidupan kebangsaan yang demokrasi dan terbuka. Maka dari itu pula membutukan kemepimpinan nasional maupun daerah yang demokratis, efektif dan efisien serta alih generasi yang damai, adil dan konstitusional. Untuk itu, Selain diperlukan penataan sistem politik, demokrasi yang bersifat substantif juga memerlukan model kepemimpinan yang transformatif. Tulisan ini bertujuan untuk menjelaskan konsep kepemimpinan transformatif yang relevan terhadap kondisi bangsa Indonesia pasca reformasi. Dengan menganalisa secara komprensif aspek historis dan realitas bangsa Indonesia saat ini berdasarkan data dan study literatur. Pentingnya kepemimpinan transfromatif yang berkarakter kepemimpinan yang tegas, adil, tanpa pandang bulu dalam menegakkan hukum, mampu menginspirasi semangat berbangsa dan bernegara untuk maju, berorientasi menyejahterakan rakyat serta mendarmabaktikan seluruh pikiran dan tenaganya untuk kemajuan negara tanpa rasa takut, untuk menggantikan model kememimpina transaksional yang didasarkan pada otoritas dan legitimasi birokrasi yang jelas-jelas merugikan negara dan rakyat sehingga negara akan stagnan dan tak ada perubahan. Pada era reformasi sekarang ini Indonesia membutuhkan kepemimpinan transformatif, yang berorientasi pada perubahan demi tercapainya tujuan, dengan melibatkan pengikutnya. Mereka memanfaatkan soft power dengan memberi contoh, memotivasi pengikut agar memiliki idealisme dalam upaya mencapai tujuan. Pemimpin transformatif memiliki kesamaan perilaku seperti Visioning, Inspiring, Stimulating, Coaching dan Team building yang dibuktikan melalui aksi nyata, berupa keputusan atau kebijakan yang tertata, terukur dalam mengatasi persoalan dengan tepat, cerdas dan tangkas.
\end{abstract}

Kata Kunci: Kepemimpinan, Transformatif, Demokrasi 


\begin{abstract}
After the 1998 Reformation, Indonesia entered an era of democratic and open national life. Therefore, there is a need for democratic, effective and efficient national and regional leadership as well as a peaceful, just and constitutional generation transfer. For this reason, apart from structuring a political system, a substantive democracy also requires a transformative leadership model. This paper aims to explain the concept of transformative leadership that is relevant to the condition of the Indonesian nation after the reform. By analyzing comprehensively the historical aspects and the current reality of the Indonesian nation based on data and literature study. The importance of transformative leadership with leadership characteristics that are firm, fair, indiscriminate in enforcing the law, able to inspire the spirit of the nation and the state to progress, oriented towards the welfare of the people and devoting all their thoughts and energy to the progress of the country without fear, to replace the transactional leadership model based on on the authority and legitimacy of the bureaucracy which is clearly detrimental to the state and the people so that the state will stagnate and there will be no change. In the current reform era, Indonesia needs transformative leadership, which is oriented towards change in order to achieve its goals, by involving its followers. They take advantage of soft power by setting an example, motivating followers to have ideals in an effort to achieve goals. Transformative leaders have similar behaviors such as Visioning, Inspiring, Stimulating, Coaching and Team building which are proven through real action, in the form of decisions or policies that are organized, measurable in overcoming problems appropriately, intelligently and agilely.
\end{abstract}

Keywords: Leadership, Transformative, Democracy

\title{
Pendahuluan
}

Seiring dengan tumbangnya Orde Baru tahun 1998 Indonesia memasuki era kebebasan berpendapat. Demokrasi pun menjadi icon baru. Sebagai konsekuensinya pemimpin dituntut untuk memenuhi kriteria-kriteria pokok yang sesuai dengan praktek pemerintahan yang demokratis, seperti amanah, sederhana dan transformatif. Tetapi bertentangan dengan harapan tersebut, setelah lima kali pemilu nasional (1998-2019) dan 1.500 kali lebih pilkada (2005-2018), yang 
cenderung muncul adalah bentuk kepemimpinan transaksional. Birokrasi tetap sulit transparan dan akuntabel. Sebaliknya, yang marak justru skandal korupsi di lembaga eksekutif, baik di tingkat nasional maupun lokal. Hal ini menimbulkan desakan kuat dari publik tentang pentingnya prasyarat yang harus dipenuhi oleh calon pemimpin ketika mencalonkan dirinya dalam pemilu presiden maupun pemilihan kepala daerah.

Lepas dari itu, pasca gerakan reformasi 1998, Indonesia memasuki era kehidupan kebangsaan yang demokratis dan terbuka. Sebagai negara demokrasi terbesar ketiga di dunia, capaian Indonesia tersebut mendapat apresiasi dari masyarakat internasional. Meskipun demikian, demokrasi yang berlangsung sejak 1998 belum dapat dikatakan telah mampu menjadikan Indonesia sebagai negara sejahtera. Secara politik masih banyak yang harus dibenahi, khususnya berkaitan dengan etika dan moral politik pemimpinnya. Nilai-nilai budaya politik yang berkembang di tengah masyarakat juga kurang bisa dijadikan penopang utama praktek demokrasi. Penyebabnya adalah absennya teladan dan atau kepemimpinan ${ }^{1}$ yang bisa menginspirasi dan mendorong perilaku positif dan mendewasakan atau mematangkan warga masyarakat dalam berpolitik.

Namun, demokrasi tanpa penegakan hukum dan kepemimpinan yang kuat berpotensi menimbulkan anarki, tirani, feodalisme, dan oligarki politik. Karena itu, keteladanan pemimpin dalam menegakkan etika dan moral menjadi sebuah keniscayaan. Nilai-nilai demokrasi Pancasila secara jelas menyiratkan hal tersebut. Atas dasar itu pula, adalah kewajiban para pemimpin untuk mewujudkan suksesi kepemimpinan nasional dan daerah yang demokratis, efektif dan efisien serta alih generasi yang damai, adil dan konstitusional. Di era kebebasan dan keterbukaan sekarang ini para pemimpin tidak bisa mengelak dari besarnya tuntutan dan harapan publik atas pemimpinnya.

\footnotetext{
${ }^{1}$ Kepemimpinan adalah suatu proses transformasi perubahan di mana etika individu menyatu dengan masyarakat banyak yang dimaksudkan sebagai evolutionary social development. Karena itu, kepemimpinan merupakan suatu proses perubahan dinamis dan pertukaran nilai-nilai.
} 
Tulisan ini ingin memberikan hasil bacaan penulis tentang harapan publik terhadap pemimpin dan kepemimpinannya.

\section{Masalah Demokrasi dan Kepemimpinan}

Gerakan reformasi 1998 merupakan klimaks gugatan rakyat yang menghendaki perubahan total menyangkut khususnya pemberantasan korupsi, kolusi dan nepotisme (KKN). Sejak Pemilu 1999 Indonesia memasuki era keterbukaan politik dan praktek demokrasi. Proses demokrasi relatif meningkatkan partisipasi masyarakat, baik di tingkat pusat maupun daerah. Dinamika politik terasakan menguat ketika desentralisasi dan otonomi daerah dilaksanakan (2001). Bahkan, dinamika tersebut semakin semarak dengan diterapkannya pilpres langsung (2004) dan pilkada langsung sejak 2005. Namun, perubahan-perubahan tersebut belum memberikan dampak positif terhadap terwujudnya tata kelola pemerintahan yang baik dan kesejahteraan rakyat.

\section{Demokasi Prosedural}

Perkembangan demokrasi sejak 1998 cenderung mengarah pada praktek demokrasi minus moral politik. Pemilu dan pilkada yang dimaksudkan untuk menghasilkan pemimpin-pemimpin yang amanah belum mewujud. Absennya budaya malu dan menurunnya etika politik menjadi kendala utama gagalnya citacita gerakan reformasi 1998. Sementara itu, yang tampak menguat justru sifat masyarakat yang cenderung permisif. Adalah jelas bahwa demokrasi yang tidak disertai dengan etika, supremasi/penegakan hukum dan kepemimpinan yang kuat akan menimbulkan anarki dan tirani kekuasaan, sehingga yang terjadi adalah feodalisme dan oligarki partai politik. Padahal, etika dan moralitas dalam berdemokrasi sangat diperlukan untuk keberlangsungan demokrasi yang sehat dan beradab.

Demokrasi memang disepakati untuk diterapkan di Indonesia, namun sisasisa atau warisan nilai-nilai masa lalu belum mampu dipotong mata rantainya, sehingga menghasilkan mix system, sistem gado-gado yaitu bercampurnya sistem 
patronase dan patrimonialisme dengan nilai-nilai demokrasi yang mengedepankan partisipasi, transparansi dan akuntabilitas. Sistem yang terbangun pasca tumbangnya Orde Baru belum mampu menghasilkan atau memunculkan pemimpin yang tepat dan amanah untuk memajukan Indonesia. Secara umum kepemimpinan nasional dan lokal kurang transformatif, di mana alih generasi berlangsung sangat lamban.

Proses demokrasi yang berjalan lamban menghadirkan Indonesia dalam transisi yang berkepanjangan. Kelambanan tersebut salah satunya disebabkan oleh pemahaman yang berbeda, misalnya, antara masyarakat dan partai politik. Demokrasi sering dimaknai sebagai kebebasan yang mutlak, bahkan kalau perlu bisa menabrak etika, rambu-rambu dan aturan yang sudah disepakati. Pelaksanaan demokrasi masih jauh dari implementasi sistemnya yang bersifat substanstif, yang menerapkan adanya partisipasi maksimal warga negara, perlindungan terhadap warga negara, keadilan ekonomi-sosial dan hukum bagi setiap warga negara.

Selain diperlukan penataan sistem politik, demokrasi yang bersifat substantif juga memerlukan model kepemimpinan yang transformatif. Kepemimpinan model ini ditandai oleh ciri-ciri kepemimpinan yang tegas, adil, tanpa pandang bulu dalam menegakkan hukum, mampu menginspirasi semangat berbangsa dan bernegara untuk maju, berorientasi menyejahterakan rakyat serta mendarmabaktikan seluruh pikiran dan tenaganya untuk kemajuan negara tanpa rasa takut.

Kepemimpinan transformatif bukan sekedar kepemimpinan yang retoris, apalagi terfokus kepada pencitraan pribadi saja, melainkan kepemimpinan yang mampu membuat kebijakan yang memihak keadilan untuk kemanfaatan rakyat. Pemimpin jenis ini memiliki kekuatan dan ketegasan dalam mengawal, mengelola dan melaksanakan kebijakannya. Indikator penting lainnya dari kepemimpinan transformatif tersebut adalah perilakunya yang jauh dari korupsi, kolusi dan nepotisme (KKN) sesuai dengan semangat gerakan reformasi 1998.

Kepemimpinan yang transformatif adalah kepemimpinan yang mengetahui dan menyadari bahwa kepemimpinan yang baik adalah yang mampu melahirkan generasi yang hebat berdasar meritokrasi, bukan nepotisme. Oleh karena itu, 
kepemimpinan model ini menyediakan sistem dan proses jalan keluar yang dapat memberi ruang bagi terciptanya alih generasi yang baik dan solid melalui sistem terbuka dan bertanggungjawab.

Pengalaman selama dua dasawarsa ini menunjukkan bahwa sistem yang berlangsung selama ini menghasilkan pemimpin yang acapkali bermasalah karena kurang memahami problem substansial yang dihadapi Indonesia. Kompleksitas masalah yang dihadapi negeri ini, baik di fora internasional maupun nasional dan lokal memerlukan kualitas pemimpin yang siap memajukan Indonesia. Calon pemimpin tak hanya memahami tantangan yang dihadapi dan mampu merumuskan serta memetakan apa yang menjadi masalah bangsa ini ke depan, tapi juga menyiapkan solusinya.

Oleh karena itu, ada beberapa aspek penting yang perlu dibenahi dan dicarikan penyelesaiannya agar permasalahan kepemimpinan, baik di tingkat lokal maupun nasional tidak menjadi kendala bagi pembangunan dan kemajuan Indonesia. Indonesia ke depan adalah Indonesia yang mampu melakukan konsolidasi demokrasi yang lebih substansial dan konkrit yang didorong oleh pemimpin yang amanah. Karena itu, Indonesia harus membenahi dan mempersiapkan secara sungguh-sungguh sistem suksesi kepemimpinan nasional dan daerah yang demokratis, efektif dan efisien serta alih generasi yang damai, adil dan konstitusional. Semua upaya ini perlu dilakukan tanpa melupakan pembenahan di internal partai politik. Karena parpol menjadi pilar penting demokrasi dan sekaligus merupakan aset negara.

Bangsa Indonesia tidak boleh membiarkan terjadinya defisit dalam berdemokrasi yang ditandai oleh banyaknya distorsi di tataran implementasinya. Meskipun demokrasi prosedural diperlukan dalam proses menuju konsolidasi, rentang waktu 1998-2015 merupakan periode yang cukup untuk mengakhiri model demokrasi prosedural ini. Terlalu lama praktek demokrasi prosedural berlangsung akan menyebabkan semakin tak berkualitas demokrasi yang kita jalankan. Masalahnya, bagaimana membangun persepsi yang sama tentang demokrasi agar demokrasi tidak mudah diselewengkan atau disimpangkan. 
Demokrasi yang dijalankan sekarang semestinya terkait dengan alinea ke-4 pembukaan Konstitusi yaitu untuk mencerdaskan bangsa dan menyejahterakan rakyat. Demokrasi adalah sistem pemerintahan dari rakyat, oleh rakyat dan untuk rakyat. Dengan demikian, demokrasi harus dilaksanakan secara konsisten. Di tataran aplikasinya demokrasi tidak boleh diterjemahkan hanya "dari rakyat, oleh rakyat", tapi untuk siapa? Demokrasi mencakup beberapa poin penting seperti: partisipasi rakyat, perlindungan terhadap warga negara, keadilan ekonomi-sosial, dan budaya (hak Ekosob), dan hukum bagi setiap warga negara. Demokrasi juga mensyaratkan ditegakkannya sistem dan aturan penegakan hukum (rule of law) yang menjadi landasan penting bagi hukum yang berkeadilan dan keamanan publik.

Selain itu, diperlukan penataan sistem yang menjamin agar warga negara taat dan tidak melanggar hukum. Yaitu suatu sistem yang mengunci peluang bagi terjadinya pelanggaran. Tak sedikit analis kebijakan publik dan politik yang mengatakan bahwa lemahnya penataan sistem cenderung memberikan kesempatan terhadap terjadinya penyimpangan, di saat transparansi dan akuntabilitas masih sangat minim dipraktekkan dan bahkan acapkali absen.

Ada beberapa hal mengapa penataan sistem tersebut penting dilakukan. Pertama, dalam konteks Indonesia, untuk mendesakkan perubahan dari demokrasi prosedural ke demokrasi substantif diperlukan penataan sistem dan leadership. Kasus Indonesia menunjukkan bahwa perubahan sistem saja tidak cukup tanpa dipandu oleh great leader yang berkarakter transformatif, yang tegas, adil, mampu menginspirasi semangat berbangsa bernegara untuk maju, berpihak pada kesejahteraan rakyat dan berani mengambil keputusan tegas.

Kedua, great leader yang transformatif mampu menjadi teladan untuk pemberantasan korupsi, kolusi dan nepotisme (KKN) dan mewujudkan tatakelola pemerintah yang baik, bersih dan melayani. Selain itu, pemimpin jenis ini biasanya mampu melahirkan regenerasi yang handal yang mempertimbangkan meritokrasi, yang memberi ruang bagi terciptanya alih generasi yang dilakukan secara transparan/terbuka dan bertanggungjawab.

\section{Pentingnya Regenerasi Kepemimpinan}


Untuk melakukan regenerasi kepemimpinan diperlukan adanya instrumen yang melahirkan pemimpin yang memiliki kemampuan, kapasitas, dan kualitas yang mumpuni. Instrumen dalam koridor demokrasi adalah partai politik yang akan melahirkan calon-calon pemimpin, baik nasional maupun lokal. Peningkatan kualitas kader-kader partai politik menjadi agenda yang mendesak. Karena dari parpollah proses regenerasi kepemimpinan berlangsung. Parpol perlu secara serius membentuk satu mekanisme pendidikan kepemimpinan yang terbuka sebagai wadah pendidikan bagi calon pemimpin nasional.

Sistem suksesi kepemimpinan nasional dan lokal perlu mengacu kepada beberapa hal pokok, seperti pemilihan langsung dilakukan di semua jenjang pemerintahan. Presiden, gubernur, bupati dan walikota dipilih langsung. Bahkan, sejak 2019 akan ada pemilu nasional serentak. Di level lokal juga dilaksanakan pilkada serentak bertahap sejak 2015. Model pemilu atau pilkada serentak tersebut diharapkan bisa menghemat biaya (efisiensi) dan menghindari kebosanan masyarakat akan pemilu.

Sejarah politik Indonesia menunjukkan bahwa proses regenerasi dan suksesi berlangsung sangat sulit. Bangsa Indonesia banyak belajar dari proses pergantian kepemimpinan dari periode ke periode, di mana proses regenerasi berlangsung sangat alot. Demokrasi mengajarkan proses perubahan yang reguler, terus-menerus dan perlu diperjuangan. Pelaksanaan demokrasi menyaratkan ditegakkannya rule of law secara riil untuk menjamin diberlakukannya aturan hukum secara berkeadilan. Demokrasi tanpa rule of law akan dibajak oleh kepentingankepentingan mafia ekonomi yang bertaut dan mempengaruhi politik dan kebijakan sehingga merugikan rakyat secara keseluruhan. Munculnya mafia peradilan, pajak, proyek, migas merupakan sebagian contoh yang dirasakan bangsa ini. Sebagai proses konsolidasi, pemilu bisa dimaknai sebagai starting point untuk mewujudkan demokrasi yang sehat, beradab dan damai. Pemilu juga merupakan langkah awal bagi Indonesia untuk melakukan suksesi yang lebih rasional dan akuntabel. 
Tantangan yang dihadapi pemimpin Indonesia ke depan adalah realitas dunia yang semakin kompleks dalam dinamika dan persaingan internasional yang semakin cepat dan ketat di berbagai lini. Selain itu, juga dinamika sosial politik, hukum, dan ekonomi domestik yang semakin tak mudah dihadapi dengan cara-cara yang linier. Kondisi demikian ini tentu memerlukan pemimpin yang berwawasan luas, terdidik, demokratis dan transformatif. Kompleksitas tantangan yang dihadapi tersebut menuntut pemimpin yang memahami kemajemukan, bukan pemimpin yang berjiwa otoritarian yang memaksakan keseragaman. Para pemimpin era reformasi adalah pemimpin yang dapat memelihara kedamaian, kemajuan, kemakmuran dan keadilan bagi bangsa Indonesia di tengah persaingan global dan regional yang semakin sengit dan mengganas.

Pemimpin Indonesia adalah pemimpin yang mampu menegaskan keberadaan Indonesia sebagai bangsa besar yang bermartabat, menolak penjajahan model baru yang datang melalui berbagai cara, eksploitasi dan intervensi asing yang merugikan bangsa dan rakyat Indonesia. Dengan demikian, seorang pemimpin harus mampu membawa kemajuan bangsa agar bangsa Indonesia menjadi pemilik negeri sendiri, tidak menyerahkan masa depan negara ke kekuatan luar, seperti menyangkut kekayaan alam dan sektor-sektor usaha penting.

Pemimpin Indonesia ke depan perlu diisi oleh figur yang memiliki track record etika yang tidak bermasalah, tidak pernah tersangkut kasus korupsi, berpihak pada penegakan hukum dan keadilan, dan tidak merugikan orang lain atau masyarakat. Seorang pemimpin juga harus berkomitmen terhadap keberlangsungan regenerasi kepemimpinan dan memperhitungkan dinamika masyarakat. Sebagai negara berkembang, pemimpin Indonesia perlu memiliki komitmen tinggi untuk menghapus kemiskinan struktural yang masih membelit bangsa. Kemiskinan bukan hanya karena mereka miskin, tapi karena lingkungan dan atau kebijakan yang menciptakan kemiskinan. Selain itu, kemiskinan terjadi karena sumber kekayaan alam telah dikuasai secara sistemik oleh kekuatan kapitalis global.

\section{Pemimpin yang Diharapkan}


Uraian tersebut di atas menegaskan bahwa pemimpin transformatif memiliki beberapa ciri penting yaitu memiliki kapabilitas dalam menerjemahkan visi kepemimpinan ke dalam rencana strategis, mampu membangun trust dan tim kerja (kabinet) yang solid dan kompeten, mampu membangun sistem dan disiplin manajemen, mampu membangun dan mewujudkan akuntabilitas publik dan sistem suksesi.

Inti kepemimpinan adalah adanya decision. Sebab, there is no leadership/leader without decision. Keputusan yang diambil pun harus tepat dan sesuai dengan tujuan nasional, berkualias, kredibel, berintegritas, dapat dilaksanakan, efektif dan akseptebel. Untuk itu, pemimpin dituntut memiliki wawasan yang luas dan jauh ke depan, khususnya terkait dengan tujuan nasional. Dalam hal ini diperlukan kemampuan menerjemahkan tujuan nasional menjadi visi yang operasional dan workable sejalan dengan perkembangan bangsa dan melaksanakannya dengan konsisten dan kemampuan untuk merumuskan misi dan strategi untuk mewujudkan visi bangsa, termasuk mengimplementasikan dengan mendayagunakan semua sumberdaya nasional. Lebih dari itu, pemimpin yang visioner perlu memiliki kemampuan untuk meyakinkan rakyat tentang misi dan strateginya, mengarahkan dan memobilisasi rakyat mewujudkan tujuan nasional.

Seorang pemimpin tidak boleh peragu, harus berani mengambil keputusan yang efektif, transformatif, cepat, tepat waktu dan akurat dalam menghadapi dan mengatasi krisis, konflik dan permasalahan genting. Ia juga mampu menjalankan keputusan/kebijakan yang diambil, bahkan mampu mengoreksi dengan cepat kebijakan yang keliru. Pada saat yang sama ia juga mampu merencanakan dan mengelola perubahan secara sistemik untuk mencapai tujuan nasional.

Seorang pemimpin perlu memiliki kecerdasan emosional (emotional intelligence) yang ditunjukkan, antara lain, melalui kemampuannya dalam menguasai diri serta kepekaan dan empati terhadap permasalahan yang dihadapi rakyat. Selain itu juga memiliki kemampuan komunikasi politik yang baik dengan kekuatan-kekuatan politik yang ada dan masyarakat luas sehingga mereka tidak resisten terhadap kebijakan yang diambil. 
Satu hal yang tidak bisa ditawar dari seorang pemimpin adalah integritas. Pemimpin harus memiliki integritas, tidak pernah tersangkut kasus/perkara yang merugikan rakyat banyak, termasuk korupsi, kolusi, dan nepotisme (KKN) serta tidak pernah tersangkut kasus/perkara yang mengurangi respek masyarakat terhadap pemimpin seperti tindakan asusila. Isu integritas ini sangat krusial akhirakhir ini seiring dengan tindakan korupsi yang merebak di mana-mana dan pelanggaran etika yang makin marak. Akseptabilitas pemimpin, antara lain, dipengaruhi oleh isu integritas. Akseptabilitas publik yang tinggi didasarkan atas dukungan yang rasional, tidak semu, seperti karena popularitas, koneksi, uang, dan keturunan. Aksetabilitas rasional muncul karena faktor kapabilitas dan integritas pemimpin.

Tantangan yang dihadapi pemimpin Indonesia ke depan akan semakin berat dan kompleks. Fenomena tersebut mensyaratkan pemimpin yang muncul nanti adalah yang berwawasan luas, seorang pemimpin transformatif yang mampu memajukan negeri. Pemimpin Indonesia perlu memiliki wawasan keindonesiaan dan kedaerahan yang cukup agar mampu menjadi kekuatan pemersatu (uniting force) NKRI. Sebagai negara berkembang yang menjalankan sistem demokrasi, Indonesia membutuhkan pemimpin yang berkomitmen memajukan bangsa dan negara melalui beberapa kebijakan terobosan yang mampu menghapus kemiskinan yang membelit bangsa. Pemimpin yang mampu membuat kebijakan yang berpihak kepada rakyat, bukan kekuatan pemodal atau kekuatan asing.

Pemimpin harus memiliki visi dan misi yang jelas tentang masa depan Indonesia yang dituangkan dalam konsep yang diketahui masyarakat. Visi dan misi yang dilaksanakan secara tegas dan jelas selaras dengan kepentingan nasional (sesuai dengan Pembukaan UUD 1945). Pemimpin nasional harus senantiasa memiliki ketegasan untuk menentukan sikap dan langkah (action) yang akan dilakukan untuk menjalankan amanat rakyat. Pemimpin memang perlu memiliki visi yang baik, namun tanpa ada ketegasan dan keberanian bertindak maka akan menjadikan pemerintahannya lemah. Dengan kata lain, ketegasan dan keberanian dalam memutuskan suatu kebijakan akan bermanfaat bagi masyarakat. 
Ketegasan diperlukan ketika pemimpin menghadapi masalah bangsa yang menuntut pengambilan keputusan yang hitam-putih. Mengambil keputusan secara jelas, tegas, dan clear akan memberikan dampak yang positif bagi bergeraknya mesin birokrasi untuk mendorong terciptanya kebijakan yang menyejahterakan rakyat.

Karena itu, yang dibutuhkan adalah kepemimpinan yang transformatif, bukan transaksional. Kepemimpinan merupakan sebuah proses pembelajaran dan praktek, bukan sebuah posisi ataupun jabatan yang diberikan. Jabatan bisa didapatkan karena uang, hubungan kekeluargaan, ataupun kolusi. Kepemimpinan adalah sebuah proses yang akan membentuk seorang pemimpin dengan karakter dan watak jujur terhadap diri sendiri (berintegritas), bertanggungjawab, berpengetahuan luas, berani bertindak sesuai dengan keyakinan, percaya diri dan mampu meyakinkan orang lain. Seorang pemimpin mampu berpikir kritis, inovatif, dan memiliki kemandirian yang cukup.

Kepemimpinan transformatif mempunyai lima dimensi. Pertama, karakter/perilaku pemimpin yang membuat para pengikutnya menghormati, mempercayai dan bersedia bekerja sama secara sadar. Kedua, perilaku pemimpin yang mampu mengembangkan inspirasi dan motivasi para pengikutnya, sekaligus menunjukkan komitmennya dan mampu menggugah spirit tim dalam organisasi. Ketiga, karakter/perilaku pemimpin yang mampu menumbuhkan ide-ide kreatif dan inovatif, memberikan solusi kreatif terhadap masalah yang dihadapi negara bangsa, dan memberikan motivasi kepada bawahan untuk mencari pendekatan-pendekatan yang baru dalam melaksanakan tugas-tugas organisasi. Keempat, pemimpin yang mau mendengarkan dengan penuh perhatian masukan-masukan bawahan dan secara khusus mau memperhatikan kebutuhan-kebutuhan bawahan. Kelima, karakter pemimpin yang memiliki ketulusan dan keikhlasan melakukan pendelegasian dan menerima pertanggungjawaban, berfikir sistem - tidak ad-hoc termasuk mau dan mampu memikirkan rencana suksesi kepemimpinan nasional.

Karakter kepemimpinan transaksional didasarkan pada otoritas birokrasi dan legitimasi di dalam organisasi. Pemimpin transaksional pada hakekatnya menekankan bahwa seorang pemimpin perlu menentukan apa yang perlu dilakukan 
para bawahannya untuk mencapai tujuan organisasi. Di samping itu, pemimpin transaksional cenderung memfokuskan diri pada penyelesaian tugas-tugas organisasi. Untuk memotivasi agar bawahan melakukan tanggungjawab mereka, para pemimpin transaksional cenderung memfokuskan diri pada penyelesaian tugas-tugas organisasi dengan mengandalkan pada sistem pemberian penghargaan dan hukuman kepada bawahannya.

Celakanya, bertentangan dengan hal tersebut, realitasnya justru karakter kepemimpinan transaksional yang diterapkan hampir di semua level organisasi/negara. Kepemimpinan transaksional memunculkan birokrasi yang paternalistik. Dan untuk memperbaiki ini dibutuhkan hadirnya mindset baru dari pemimpin organisasi/negara untuk melakukan transformasi, baik secara struktural maupun kultural agar upaya untuk mensejahterakan rakyat dapat diwujudkan.

Indonesia tak seharusnya berkutat dengan pola kepemimpinan yang transaksional yang jelas-jelas merugikan negara dan rakyat. Negara akan stagnan dan tak ada perubahan. Kepemimpinan yang transformatif memiliki visi kepemimpinan yang jelas, sehingga mampu 'bring vision into action'. Implementasi program jalan, proses motivasi dan pemberdayaan juga jalan. Dengan kata lain, seorang pemimpin memiliki tanggung jawab kepemimpinan yang meliputi, antara lain, mampu menerjemahkan visi kepemimpinan nasional ke dalam rencana strategis; mampu membangun trust dan tim kerja (kabinet) yang solid dan kompeten; mampu membangun sistem dan disiplin manajemen; mampu membangun dan mewujudkan akuntabilitas publik; dan mampu membangun sistem suksesi.

Dalam konteks demokrasi, prinsip akuntabilitas sangat penting. Bangsa Indonesia memiliki kelemahan mendasar dalam hal komunikasi, koordinasi, kerjasama dan komitmen. Bila komunikasi buruk, otomatis koordinasi tidak berfungi. Jika koordinasi tidak berfungsi, kerjasama tidak akan jalan. Bila kerjasama kacau, akan mengakibatkan rendahnya komitmen. Tanpa komitmen, tidak akan terjadi kesungguhan untuk memberikan best effort. Lantas, bagaimana nasib negeri ini bila pemimpin tak memiliki kepemimpinan yang bervisi menyejahterakan rakyat? 
Kepemimimpinan atau sistem kepemimpinan mestinya mampu membangun disiplin sistem dan membangun sistem suksesi dalam negara dengan baik. Bangsa Indonesia memiliki nilai-nilai budaya bangsa luhur, seperti tersirat dalam pepatah lokal yang menggambarkan kepemimpinan 'ing ngarso sung tuladha - ing madya mangun karsa - tut wuri handayani. Dengan kata lain, seorang pemimpin itu mestinya 'leading - inspiring - motivating'. Leadership wisdom merupakan hasil akumulasi knowledge, skill dan attitude yang positif dalam konteks kepemimpinan.

\section{Penutup}

Kepemimpinan di era reformasi sekurang-kurangnya memenuhi beberapa kriteria penting. Dalam kehidupan demokrasi yang telah mapan, sistem lebih berpengaruh daripada pemimpin. Ini karena demokrasi mengajarkan pemimpin bekerja dalam sistem. Dalam konteks Indonesia, membangun sistem sangatlah penting. Namun, realitasnya peran pemimpin relatif lebih dominan dan atau menentukan. Ada tiga alasan penting mengapa ini terjadi. Pertama, proses transisi mensyaratkan pemimpin mampu membuat keputusan yang tegas, tepat dan in time dalam mengatasi permasalahan krusial yang muncul. Kedua, pemimpin era reformasi juga harus mempunyai kelebihan dibanding pemimpin dalam keadaan normal. Karena itu pemimpin era reformasi diharapkan menjadi great leader dengan strong leadership untuk membawa rakyat menapaki dan mewujudkan tujuan nasional.

Ketiga, pemimpin juga dituntut untuk ikut mengembangkan dan memantapkan sistem yang ada agar konsolidasi demokrasi dapat segera berjalan. Mengapa keputusan yang tegas, tepat dan in time amat diperlukan di era reformasi? Suatu bangsa yang sedang menjalani era reformasi menghadapi empat situasi genting, yaitu (a) Keputusan saat kritis memiliki implikasi signifikan karena terkait kebutuhan masyarakat yang paling mendasar dan masa depan mereka. Keputusan akan berpengaruh, baik secara ekonomi, politik, maupun sosial dan kemanusiaan. (b) Keputusan saat kritis bersifat dilematis, memaksa pemimpin harus memilih apakah aspek politik diselamatkan yang berarti popularitas seorang pemimpin 
dikorbankan atau aspek lainnya seperti ekonomi (dukungan mesti dikorbankan, dan sebaliknya). (c) Keputusan saat kritis juga cenderung tidak pasti. Namun, kondisi kritis mendesak pemimpin untuk mengambil tindakan tegas dan berani. Selain itu, (d) keputusan saat kritis menghajatkan kesigapan. Tak ada kemewahan waktu, juga tidak bisa berlama-lama dalam kehati-hatian, dan bahkan tidak boleh memanjakan keraguan.

Pengalaman bangsa lain menunjukkan bahwa situasi kritis dan proses transisi dapat melahirkan pemimpin besar (great leader) dibandingkan dengan situasi mapan dan normal. Great leader akan muncul kalau pemimpin tersebut mempunyai visi dan karakter sebagai modal dasar bagi kapabilitas dan integritas kepemimpinannya.

Dengan kata lain, di era reformasi sekarang ini Indonesia membutuhkan kepemimpinan transformatif, bukan transaksional. Pemimpin yang transaksional cenderung mengambil keputusan dengan pertimbangan untung-rugi (seperti proses perdagangan), bukan benar-salah atau tepat-menyimpang. Mereka mengandalkan hard power seperti perintah, rewards, hukuman dan kepentingan pribadi (selfinterest). Kegiatan yang dilakukan bersifat simbolik. Kehadiran simbolik tersebut ditandai dengan keberadaan fisik sang pemimpin di tengah masyarakat yang dirundung krisis, kunjungan ke dan pidato di lokasi bencana.

Sedangkan pemimpin transformatif cenderung berorientasi pada perubahan demi tercapainya tujuan, dengan sejauh mungkin melibatkan pengikutnya. Mereka memanfaatkan soft power dengan memberi contoh, memotivasi pengikut agar memiliki idealisme dalam upaya mencapai tujuan. Pemimpin transformatif memiliki kesamaan perilaku seperti Visioning (memberikan rumusan masa depan); Inspiring (menimbulkan kegairahan); Stimulating (menimbulkan minat); Coaching (memberikan bimbingan); dan Team building (bekerja melalui team-work). Kegiatan yang dilakukan bersifat fungsional. Kehadirannya secara fungsional tersebut dibuktikan melalui aksi nyata, berupa keputusan atau kebijakan yang tertata, terukur dalam mengatasi persoalan dengan tepat, cerdas dan tangkas. 


\section{Daftar Bacaan}

Antlov, Hans, Leadership on Java. Routledge, 1994.

Zuhro, R. Siti, 'Permasalahan Kepemimpinan Politik Lokal dan Nasional', makalah disampaikan dalam Seminar Refleksi Akhir Tahun Bidang Politik dan Pemerintahan Universitas Muhammadiyah Malang (UMM), Malang, 10 Desember 2013.

Zuhro, R. Siti, 'Kepemimpinan dan Etika Pemerintahan', makalah dipresentasikan dalam seminar yang diselenggarakan Kesbang Politik Kemendagri, Makassar, 1 Oktober 2013.

Zuhro, R. Siti, 'Pentingnya Nilai-Nilai Budaya Lokal, Peran Aktor dan Institusi Demokrasi dalam membangun Demokrasi yang Sehat, Beradab dan Berkualitas', dalam Dialog 'Membangun Sistem Demokrasi Indonesia', yang diselenggarakan oleh Lemhannas, Jakarta, 14 Agustus 2014.

Zuhro, R. Siti, 'Membangun Kepemimpinan yang Kuat dan Berkarakter', makalah dipresentasikan dalam RTD Pengembangan Hanjar Kursus Singkat Manajemen Pertahanan Negara, yang diselenggarakan oleh Kemhan, Jakarta, 29 Oktober 2014. 